\title{
Effect of Weight Training Exercises to Develop Speed and Shoulder Strength among Javelin Throwers of Acharya Nagarjuna University Guntur
}

\author{
P.P. Satya Paul Kumar \\ Principal and Director \\ University College of Physical Education \& Sports Sciences \\ Acharya Nagarjuna University, Nagarjuna Nagar -522 510 \\ Guntur, Andhra Pradesh, India \\ ppspaulkumar@gmail.com
}

\begin{abstract}
-weight training is a common type of strength training for developing strength and skeletal muscles. Sports where weight training is the central includes bodybuilding, weightlifting, power lifting, highland games, short-put, and javelin throw. This study investigated the effect of weight training exercises for the development of speed and shoulder strength in Javelin Throwers. Twenty (20) male javelin throwers of Acharya Nagarjuna University, Guntur were used as samples in this study; out of which ten (10) were experimental group and the other (10) were controlled group. Weight training exercises were given to experimental group on alternate days i.e. three sessions per week while control group were given general training for six weeks. Pretest and posttest were conducted on 30 meters run and pull ups to the experimental group and controlled group. This study shows that there is an improvement in speed and shoulder strength of experimental group due to the weight training exercises. Therefore, it is concluded that due to weight training exercises there will be an improvement in speed and shoulder strength among Javelin throwers.
\end{abstract}

Keywords - weight training, shoulder strength, speed

\section{INTRODUCTION}

Weight training is a common type of strength training for developing the strength and size of skeletal muscles. Force of gravity weight (in the form of weighted bars, dumbbells or weight stacks) is used to oppose the force generated by muscle through concentric or eccentric contraction. Variety of specialized equipment is used in weight training to target specific muscle groups and their types of movement.

There are several sports where strength training is central and these include bodybuilding, weightlifting, power lifting, strongman, highland games, short-put, discus throw, and javelin throw. Many other sports uses strength training as part of their training regimen, these include mixed martial arts, American football, wrestling, rugby football, track and field, rowing, lacrosse, basketball, baseball, and hockey. Strength training for other sports and physical activities is becoming increasingly popular.

The javelin throw is a track and field event where the

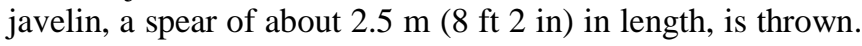
The javelin thrower gains momentum by running within a predetermined area before throwing the javelin. Javelin throwing is an event of both the men decathlon and women heptathlon..

According to Sing (1984), javelin used in fighting war are generally heavier than those used for competitions. However, there has been technological advance in the design of javelin over the years; modern javelins are now made of Aero dynamic material. The advancement in javelin technology has come so far that rules had to be implemented to keep the javelins from flying out of stadiums. The modern javelin weight is 800 grams for the men Section and 600 grams for women section. Aerodynamics as well as many biomechanical principles must be considered in determining the optimal method of throwing to achieve the greatest distance. According to Lawson (1997), Jan Zelezny now holds the world record with new Javelin throw of 98.48 meters.

\section{METHODS AND MATERIALS}

The purpose of this study is to investigate the effect of weight training exercises for the development of speed and shoulder strength in javelin throwers. Twenty (20) male javelin throwers of Acharya Nagarjuna University, Guntur were used for this study; out of which 10 are experimental group and the remaining 10 as the control group

The following are the weight training exercises given to the experimental group three times a week for eight weeks Biceps Curls:

$\begin{array}{ll}\text { 1. } & \text { Triceps Curls } \\ \text { 2. } & \text { Bench Press } \\ \text { 3. } & \text { Back Press } \\ \text { 4. } & \text { Bent Over Rowing } \\ \text { 5. } & \text { Up right Rowing } \\ \text { 6. } & \text { Wrist Curls } \\ \text { 7. } & \text { Half Squats } \\ \text { 8. } & \text { Full Squats } \\ \text { 9. } & \text { Dead Lifts } \\ \text { 10. } & \text { Good Morning } \\ \text { 11. } & \text { Side Wards Bend } \\ \text { 12. } & \text { Heel raising with weights } \\ \text { 13. } & \text { Leg Press } \\ \text { 14. } & \text { Push ups } \\ \text { 15. } & \text { Sit Ups } \\ \text { 16. } & \text { Medicine Ball Exercises } \\ \text { 17. } & \text { Dumbbell Exercises }\end{array}$


These weight training exercises were given to experimental group on alternate days i.e. three sessions per week, while the control group were given general training for six weeks. Pre test and post test were conducted on 30 Meters Run and Pull Ups to the experimental group and control group.

\section{RESULTS AND DISCUSSION}

The result of this study shows that experimental group javelin throwers have increase in speed and shoulder strength due to weight training exercises, compare to the control group javelin throwers which are involved in the general javelin training.

TABLE I. MEAN VAlues AND PAIRED SAMPLES Statistics OF PULL UPS BETWEEN EXPERIMENTAL AND CONTROL GROUPS OF JAVELIN THROWERS OF ACHARYA NAGARJUNA UNIVERSITY, GUNTUR

\begin{tabular}{|c|c|c|c|c|c|}
\hline $\begin{array}{c}\text { Vari } \\
\text { ables }\end{array}$ & Group & $\begin{array}{c}\text { Pre Test } \\
\text { Mean } \pm \text { SD }\end{array}$ & $\begin{array}{c}\text { Post Test } \\
\text { Mean } \pm \text { SD }\end{array}$ & t & $\begin{array}{c}\text { P - } \\
\text { Value }\end{array}$ \\
\hline \multirow{2}{*}{$\begin{array}{c}\text { Pull } \\
\text { Ups } \\
\text { Test }\end{array}$} & Experimental & $8.33 \pm .479$ & $12.73 \pm .868$ & 4.4 & 0.000 \\
\cline { 2 - 5 } & Control & $8.27 \pm .450$ & $7.80 \pm .714$ & 7 & \\
\hline
\end{tabular}

*Significant at 0.05 level

The mean of the experimental group performance in pull ups of pre-test is 8.33, while there is improvement in performance to 12.73 in post-test. This shows that experimental group has improved in mean value by 4.40 due to the weight training exercises from Pre-test to Post-test.

The mean performance of the control group in Pull Ups of Pre-test is 8.27, while there is decrease in performance to 7.80 in Post-test. This shows that there is decrease in the control group mean value by 0.47 due to the general training from Pre-test to Post-test.

TABLE II. SHOWING MEAN VALUES AND INDEPENDENT SAMPLES TEST OF 30M RUN TEST BETWEEN EXPERIMENTAL AND CONTROL GROUPS OF JAVELIN THROWERS.

\begin{tabular}{|c|c|c|c|c|c|}
\hline $\begin{array}{r}\text { Vari } \\
\text { ables }\end{array}$ & Group & $\begin{array}{c}\text { Pre Test } \\
\text { Mean } \pm \text { SD }\end{array}$ & $\begin{array}{c}\text { Post Test } \\
\text { Mean } \pm \text { SD }\end{array}$ & $\mathbf{t}$ & $\begin{array}{c}P \text { - } \\
\text { Value }\end{array}$ \\
\hline \multirow{2}{*}{$\begin{array}{c}\mathbf{3 0} \\
\text { M } \\
\text { Run } \\
\text { Test }\end{array}$} & $\begin{array}{c}\text { Experimen } \\
\text { tal }\end{array}$ & $3.49 \pm 0.115$ & $3.27 \pm 0.154$ & $\begin{array}{l}1 \\
0\end{array}$ & \multirow{2}{*}{0.000} \\
\hline & Control & $3.58 \pm 0.102$ & $3.65 \pm 0.090$ & $\begin{array}{l}6 \\
2\end{array}$ & \\
\hline
\end{tabular}

The mean performance of experimental group in 30 meters run in Pre-test is 3.49, and there is improvement in performance to 3.27 in Post-test. This means that experimental group has improved in mean by value of 0.22 due to weight training exercises form Pre-test to Post-test. Also, the mean performance of control group in 30 meters run in Pre-test is 3.58, and there is decrease in performance to 3.65 in Post-test. This means that there is decrease in control group mean by 0.07 due to the general training from Pre-test to Post-test. Javelin throwers requires good shoulder strength and speed to throw more distance.
This study shows that the weight training exercises causes improvement in speed and shoulder strength of the experimental group. Therefore, it is concluded that due to weight training exercises, there is improvement in the speed and shoulder strength among Javelin throwers.

\section{CONCLUSIONS}

In this study, it is concluded that weight training exercises causes increase in speed and shoulder strength of javelin throwers. According to the laws of physics, release velocity has the greatest influence on distance attained in any throwing event. This includes both the guiding and target parameter. Therefore, release velocity should always be maximized while the values of the other factors should be optimal. Final acceleration phase is very important in javelin to achieve higher performance.

\section{RECOMMENDATIONS}

It is recommended that similar studies should be conducted on other events in athletics, and also on female javelin throwers. This study is useful to coaches so they can give proper coaching to javelin throwers, for the development of motor qualities for improvement in performance.

\section{REFERENCES}

[1] C. H. Brown, B. Sing, and B. Webb, Chapter 16: Javelin. In: USA Track and Field Coaching Manual. Champaign, IL: Human Kinetics, 2000. pp. 249-264.

[2] G. Schmolinsky, Track and Field the East German Text Book of Athletics, Toronto, ON: Sports Books Publisher, 2004.

[3] T. Naclerio, Teaching Progression of the Shot put, Discus and Javelin Rock away

[4] G. Lawson World Record breakers in track and field athletics, Champaign II: Human kinetics, 1997.

[5] R. Sing, The dynamics of the javelin throw, Cherry Hill, NJ Reynolds publishers. 1984.

[6] www.topendsports.com 